\title{
Declamation and Philosophy
}

\author{
Michael Winterbottom \\ University of Oxford \\ United Kingdom
}

\begin{abstract}
Resumo. Declamação e Filosofia. Cícero estava ansioso para promover uma reconciliação entre a oratória e a filosofia que, pensava ele, estavam separadas uma da outra desde os tempos de Platão. Ele imaginava que um orador deveria ser capaz de falar sobre questões abstratas e de mover-se livremente entre o geral e o particular, e que o treinamento na oratória deveria ter alguma fundamentação na filosofia. Este ensaio argumenta que a educação retórica que floresceu depois de Platão levou esses pontos em consideração, e que na Segunda Sofística, como na Primeira, era possível a um único homem ser orador e também filósofo.

Palavras-chave. Educação, Declamação, Filosofia, Cícero, Filostrato, Primeira Sofística, Segunda Sofística.
\end{abstract}

Two familiar ancient sources formulated models for the history of the relationship between oratory and philosophy from the fifth century $\mathrm{BC}$ on.

Philostratus, writing in the first half of the third century AD, distinguished two Sophistics (VS 480-4). The 'old' Sophistic, founded by Gorgias, he sums up as 'rhetoric philosophising'. Unlike philosophy itself (Philostratus means philosophy as it developed later), it assumed the truth of what it spoke of; and it dealt with philosophical themes 'diffusely and at length' (Philostratus here implies another contrast with developed philosophy). The examples given are courage, justice, heroes and gods, and the manner in which the universe received its shape. The rather later 'second' Sophistic, on the other hand, was concerned with type characters, poor men and rich men, war heroes and tyrants, and treated tas es onoma hupotheseis, particular cases involving named persons. Hupothesis is the ordinary term for the theme of a declamation. The rhetorician Hermagoras had in the Hellenistic period contrasted it with the general thesis. And though Philostratus does not use that term, he is clearly thinking of the Hermagorean distinction. The fifth-century sophists spoke on abstract 'philosophical' topics, theseis. Later

\footnotetext{
${ }^{1}$ Corpus Christi College.
} 
sophists, what we tend to call rhetores or declaimers, treated particularised though fictional cases, hupotheseis.

The other model was that of Cicero (De orat. 3.60-1). He looked back to a period when philosophy and rhetoric were united, taught and practised by the same persons. But then came a split, attributed to Socrates, as a result of which the two had been lastingly separated. Philostratus' model does not explicitly state that the first sophists concerned themselves with all topics, not just philosophical ones. But that is the implication of the story both he (VS 482) and Cicero (De orat. 1.103) tell, of how Gorgias would speak on any topic suggested by his audience. In that case, Cicero's model is in essentials identical to Philostratus'. But whereas Philostratus talks of sophists, Cicero, no friend of rhetores, talks of oratory and philosophy. Both, however, see a crucial break in the fourth century. For Cicero, in blaming it on Socrates, is really thinking of the influence of the anti-rhetorical dialogues of Plato (d. 347), while Philostratus thinks of Aeschines (d. c. 322) as founder of the Second Sophistic.

Cicero himself had changed his mind about philosophical topics. In his youthful De inventione (1.8), perhaps echoing his philosophy teachers, he was sharply, and no doubt unfairly, critical of Hermagoras for including in the field of the orator such (Old Sophistic) questions as 'Is anything good except honestas?' and 'What is the shape of the world?'. But in his maturity, he was highly sympathetic to some kind of rapprochement between oratory and philosophy. We may distinguish three aspects of his mature view. Two concern oratorical, the third educational practice:

a) Cicero came to see that even the forensic orator could not avoid talk of abstract matters. Thus he makes Crassus say (De orat. 1.56) that passages 'very often' come up in which an orator must talk of the gods, or the ius gentium, or the various virtues. He represents the philosophers as crying out that all this is their field. But there was the crucial matter of style. If orators discussed such topics, it was 'with all pleasantness and gravity', in contrast to the plainness of the philosophers (ibid. 1.57): much the same contrast as we saw implied in Philostratus. Later, in the important preface to the Paradoxa Stoicorum, Cicero commends the Stoic Cato for being able to make his 'grave' passages from philosophy acceptable even to senate and people: something easier for the less doctrinaire Cicero. In praising Cato, Cicero praises himself. Both brought philosophical themes into oratory. They will not, perhaps, have been the only Roman orators who did so.

b) In particular, Cicero became convinced that it was the mark of a great orator to move freely, where possible, between the general 
and the particular (e.g. Orat. 45). It is not clear how he came to this view; perhaps from reflection on what he had instinctively done in his own speeches. We may think, for example, of the generalised question discussed in Pro Milone 7-11.

c) Finally, so far as education was concerned, Cicero was (at least in the case of his nephew) happy enough that it should be conducted in the usual manner, involving declamation on imaginary but particular themes. Yet, he writes to his brother in 54 BC (Ep. Quint. 3.3.4), you know that my preferred method is 'a little more scholarly and philosophical (thetikoteron)'; and when the young man is with Cicero in the country, he looks forward to initiating him in this deeper kind. Five years later Cicero (Ep. Att. 9.4) was declaiming on a number of general questions for practice, choosing topics poignantly relevant to his own position (the one he mentions first is: 'Should one remain in one's country under a tyranny?'). He spoke on both sides of these questions. That was the philosophers' way. But there was practical point: Cicero was trying to make up his mind.

This three-pronged attempt to reconcile oratory and philosophy Cicero represents as a novelty of his own. A modern scholar, Jakob Wisse, has used the words 'idiosyncratic and surprising'. ${ }^{2}$ But I shall suggest that Cicero was doing little more than bring into the realms of theory what had long been practised under the teachers of rhetoric who had, as he says in the letter to Quintus I have quoted, trained him in declamation. It is in the nature of the case that we know little of declamation before Seneca the Elder wrote in the early Empire. But the rhetores were a conservative lot, and I see no reason why we should not in this matter argue back from Seneca, and from even later evidence, Greek and Latin. In particular, there seems no doubt that progymnasmata, the preliminary exercises in rhetoric, went back well before the Christian era.

I touch first on the inclusion of abstract material in a speech. Seneca on several occasions draws our attention to passages of what he calls philosophising, some spoken by an avowed philosopher, Fabianus, others by an admirer of Fabianus, the older C. Albucius Silus. I give a single example. Seneca introduces $(C .7 .6 .18)$ with the words 'Albucius philosophatus est' a passage on slavery: no one is free or slave by nature, for these are only names imposed on men by Fortune. It is easy to find parallels for this idea in the Younger Seneca, a practising philosopher. ${ }^{3}$ But one did not have to be a

2 (Ed. James M. MaY) Brill's Companion to Cicero (Leiden, 2002), 397.

${ }^{3}$ See my note ad loc. in the Loeb edition. 
philosopher to declaim on such a theme; there is an eloquent passage on the topic in Decl. Mai. 13 (c. 8), and the author of the Minor Declamations puts it succinctly: 'sortimur genus, non eligimus' (388.22). Many declamation themes involved slaves, and the topic was inevitable. It is telling that (as we know from Aristotle's Rhetoric 1373b18) Alcidamas, back in the first Sophistic, remarked that 'the gods made all men free, and Nature has enslaved no one'. To a modern ear all this does not sound exactly like philosophy. But that is just the point. At this level the concept of a reconciliation of rhetoric and philosophy is vacuous, for such moralising permeated most types of discourse. When Mayor gives parallels for Juvenal's 'utque animas seruorum et corpora nostra / materia constare putet paribusque elementis' (14.16-17), he mentions, among others, Philemon, Petronius, and Cyprian. And it is at this level that Cicero is talking. When he says that orators often speak, say, of the gods, he does not mean a technical Stoic or Epicurean disquisition; he means an uplifting passage on Iuppiter Optimus Maximus.

A second passage where the Elder Seneca catches Albucius philosophising may serve as a transition to Cicero's call for free movement between general and particular. Cestius is said (C. 1.3.8) to have criticised Albucius for treating as problemata philosophumena what Cestius thought were merely minor offshoots of the quaestio 'an haec [a Vestal who survived precipitation from the Tarpeian Rock] deorum adiutorio seruata sit': namely 'an di immortales rerum humanarum curam agant; etiamsi agunt, an singulorum agant; si singulorum agunt, an huius egerint'. I shall return to the substance of the quaestio here, the role of Providence in human life; meanwhile, we should note how Albucius moves from the general (do Gods care?) to two successive stages of particularity (Do they care about individuals? Did they care about this woman?). This movement is highly typical of the procedures of declaimers in Seneca, most of whom were not philosophers at all. They will have been taught to structure their arguments like this at the school of the rhetor; and those who wonder what Hermagoras did with his distinction between thesis and hupothesis may look for their answer here. Nor is Seneca our only source. In the Minor Declamations, we find (299.2) the Master prescribing as a first question 'an utcumque ['under all circumstances'] sepultum eruere non liceat'; there follow two more of increasing particularity, and yet others that he calls speciales quaestiones. Some philosophical teaching may lie behind this sort of thing. But its roots lie deep in the mentality of classical writers; recall how Pindar moves from maxim to example, or Horace (Carm. 3.12) from 'miserarum est neque amori dare ludum ...' to 'tibi qualum Cythereae puer ales, tibi telas .... Here again Cicero is not really innovating; declamation already did what he required of the orator, and the classical mind was well attuned to such a course. 
I come now to theseis. When Cicero practised them himself, he did so, as we have seen, in the proper philosopher's manner, taking first one side and then the other. But such pro and contra treatment was not essential, as we see when we consider the practice of the rhetores. For they made thesis one of the progymnasmata that, from some (I take it Hellenistic) date were used to introduce students to rhetoric; and it was surely not expected of a pupil at this tender age that he should speak on both sides of such topics on the same occasion. And the examples given by e.g. Libanius point that same way. More important, the link between progymnasmatic thesis and philosophers was clear to rhetorical writers. Thus Quintilian's remark (2.1.9) that the antiqui spoke theseis is to be glossed by a passage in Book 12 (12.2.25), where he comments on the way in which the Peripatetics virtually (fere) instituted the speaking of theseis for training in speaking. More explicitly, the Greek rhetor Theon, probably writing in the first century AD, tells us that examples of theseis are easily to be found in Aristotle and Theophrastus, who wrote books with that title (p. 69 Spengel). When Cicero commended his 'more philosophical' method for the education of his nephew, he was pushing at an open door.

It may be objected that the sort of thing a child of twelve might come up with, even with a lot of prompting, on a general topic would hardly be sophisticated enough to count as philosophical. All the same, the exercise did help a boy to think and talk in general terms. It is in any case crucial to remind ourselves that practice in the thesis did not stop at the progymnasma stage. On the contrary, like all the exercises that made up that early course, it was only introduced there. When a boy came on to declamation proper, he would discover that the thesis was a building block that he could insert into the fabric of a full speech (I shall come back to this matter). Similarly, it might prove useful when he eventually made a speech in court. This is what Quintilian means when he says that all the early exercises 'crop up in forensic cases' (2.1.10). Here again, Theon confirms: he says (p. 69 Spengel) that we may look for instances of thesis in, for example, two (apocryphal) speeches by Lysias. And Quintilian points to the use made by Cicero in his pro Murena of the thesis comparing law and soldiering (2.4.24), as well as to the way in which the great orator practised oratory in his maturity by speaking on such general topics (10.5.11, perhaps with a reference wider than just to the sort of thing we saw in Ep.Att. 9.4). In this way, the thesis could play a role in exercising for oratory from childhood to old age. It may be added that the old Seneca (2 pr. 4-5) encouraged his son Mela to study eloquence if only as a means to other arts, citing the case of Fabianus, who went on from declamation to dialectic (he was equally obscure, it seems, in both departments). It follows that it was not a matter of choosing between rhetoric and 
philosophy. It was possible and even inevitable to start in the school of the rhetor before moving to the school of the philosopher: a move, indeed, that might well take a student from Rome to Athens. Cicero, and Quintilian, after him, were over-ready to polarise the subjects.

We have a good deal of information on the way in which general questions were employed in declamation. Theon (p. 121 Spengel) distinguished two kinds of thesis: a) practical, e.g. 'Should one marry?', and b) theoretical, e.g. 'Do the gods take thought for the world?' (he gives detailed headings for this at p. 126-8 Spengel). It is obvious, he goes on, that the practical ones are "more political' and are 'in accordance with the "character" of rhetoric', while the theoretical 'are suitable rather to the philosophers'. But, he adds significantly, it is possible for rhetoricians to treat them too. It was possible, we may note, because the rhetores made it possible. Albucius was criticised (C. 7 pr. 8 ) for asking in one controversia: 'Why does a cup break if it is dropped, but a sponge doesn't?' (on which Cestius commented: 'Go and listen to him tomorrow: he'll tell you why thrushes fly and pumpkins don't'). The objection to this question was presumably that it was irrelevant to the theme. But themes could be so designed as to make 'philosophising' desirable or inevitable.

To take the example of the role played by the gods in the world. Quintilian comments interestingly on it (5.7.35). The thesis 'Is the world ruled by providence?' is, he says, part of the eternal battle between Stoics and Epicureans. As for the particular question, it would (Quintilian says) vary according to the case and the type of forecasting of the future it involved. Seneca's third Suasoria may provide an example. The theme is 'Agamemnon deliberates whether to sacrifice Iphigenia, it being Calchas' pronouncement that otherwise it is impossible to set out to sea'. The particular case here concerns augury; note how Pompeius Silo says (4) that even if some methods of divination work, no belief should be placed in augury. As for the thesis, we may turn to the division by Cestius (3): 'a) the gods do not make their wishes felt in human affairs; b) even if they do, men cannot know their will; c) even if men do know it, the fates are irrevocable.' (It may be observed how vividly this recalls the argument of Gorgias' On Nature back in the first sophistic: Nothing exists; even if it does, it is incomprehensible; even if it is comprehensible, it is not communicable. Plus ça change.) Less schematically, Arellius Fuscus argued that the delay at Aulis was due to natural causes, sea and wind; as for the will of the gods, that was not to be known by mortals.

Seneca of course gives us no more than short extracts from declamations, or summaries of their arguments. We have to turn to the fourth of the Major Declamations, of uncertain date but much later than Seneca, to see the 
thesis argued in detail. The theme makes discussion of the point inevitable, and was chosen, surely, with that in mind. A man opposes the suicide of his son, of whom it had been predicted by an astrologer (mathematicus) that he would go on from being a war hero to killing his father. The declaimer, speaking as the son, devotes two pages to the general topic (13-14). We may note two points in particular. 1) The son represents his father as having argued that there is no fate, only chance; but that even if providence rules all things ('etiam ut prouidentia regantur'), it is not open to human comprehension. The continuity of declamation from the $4^{\text {th }}$ century BC to (perhaps) the $4^{\text {th }} \mathrm{AD}$ is splendidly obvious. 2) Much of the wording of these paragraphs is taken almost without change from Concerning the Error of Profane Religions, which Firmicus Maternus wrote in the fourth century after his conversion to Christianity. Declamatory topics were not to be rendered out of date by a mere change of the empire's religion.

It might be thought that more 'physical' theseis could not readily be introduced into declamation: such topics as Hermagoras' 'What is the shape of the earth?' Yet look at the first Senecan Suasoria, in which Alexander, having reached India, is advised on whether or not he should proceed to sail across the Ocean. The philosophers have a field day here, and, even if wordy, they are not being irrelevant. Fabianus says that those who have succeeded in calculating the movements of the stars, "men to whom no part of the universe is a mystery, are still in doubt as to the Ocean' (4); and he proceeds to specify competing ideas about the Ocean's nature. More concisely, Albucius asserts (3) that 'even the earth has its end; the very universe sets somewhere'. But anyone talking on such a theme could hardly avoid taking some explicit stand on the nature of the world. It was probably not a philosopher who said (1): 'Beyond everything, the Ocean; beyond the Ocean, nothing.' The theme, attractive in other ways, cries out for some treatment of this 'physical' thesis.

Quintilian, as appears from two passages $(2.1 .9,2.4 .36)$, thought of all the progymnasmata as being in some sense general, presumably because they did not treat hupotheseis, particular cases. But the most obviously general of the whole lot was the locus communis or commonplace. And of this I should say a little. A precise distinction between this and the thesis is formulated by Theon (p. 120 Spengel), who makes the commonplace the amplification of something that is agreed, aiming at the punishment of an offender, the thesis the amplification of something that is disputed, aiming at persuasion. This distinction was not universally accepted. While Quintilian thinks (2.4.27) of the discussion of e.g. witnesses in general as being a locus, Theon (p. 69 Spengel) calls the comparable discussion of rumour and torture theseis. What matters for our purposes is that the progymnasmatic 
exercise of commonplace, like that of thesis, was something that gave a student practice in generalised, if not abstract, thought; and commonplace, too, was a building block for declamation and found its way into real oratory (Theon [p. 67-8 Spengel] gives examples from Demosthenes). Thus, the early exercises lay a firm foundation, by no means restricted to theseis, for generalising oratory.

After all these abstractions, I turn finally to some real people: just as Philostratus, having set up the model of the two Sophistics that I began with, gave potted biographies of individual sophists. We may note that he says that earlier in the Second Sophistic the name sophist was given not just to distinguished orators but also to philosophers who 'expressed themselves with fluency' (484); and it is with such persons that he begins. Six precede Dio of Prusa. The best known is Carneades, on whose forceful oratory Philostratus comments (486). It is well known from other sources that on an embassy to Rome in 155 he spoke for and against justice on consecutive days. We think of him as a philosopher; but this sort of bravura performance reminds us how closely such persons followed in the footsteps of the old sophists, shocking audience with their paradoxical assertions. Similarly, the much earlier Eudoxus of Cnidus is said by Philostratus (484) to have had an ornate style and to have improvised well; Philostratus talks of his links with the Academy, but he might also have mentioned his remarkable versatility in philosophy as geometer and astronomer. We may add to Philostratus' list Apuleius of Madaura, who was both Platonist and declaimer, not to speak of law court orator and novelist.

We hear of Euphrates of Tyre from Latin sources as well as Greek. Both Philostratus (488) and Pliny (Ep. 1.10) regarded him as a philosopher. Pliny describes him as disputing 'subtiliter grauiter ornate', often attaining the sublimity and width of Plato with a style that was 'copiosus et uarius, dulcis in primis': all this despite his formidable appearance, the tall frame, the long hair, the enormous white beard. It would seem that the borders between philosophy and even dialectic on the one hand, and rhetoric on the other, were easily crossed. Seneca (Ep. 40.2) frowned on the effusive style of the philosopher Serapio ('more came to him than a single voice is capable of uttering'). But, he reflects, such licentia is a Greek fault (ibid. 11).And he praises for a proper Roman eloquence our old friend Fabianus (12), whom he commends for 'disputing' with facilitas rather than celeritas. The same philosopher is praised in another of Seneca's letters (100.5-6) for sentences that are not 'forced into epigram' but spoken latius. Seneca is contrasting different types of oratorical style as employed by philosophers; he is not (as we saw Crassus doing in the De oratore) associating one style with philosophy, another with oratory. 
Cicero, in short, seems much to exaggerate the split between rhetoric and philosophy. We have seen evidence from both before and after his day to suggest that the old First Sophistic tradition of eloquent philosophy and philosophical eloquence was by no means forgotten. It may be that Cicero exaggerated in order to show in the best light his own proclaimed achievement in reconciling the two. Of course, the sort of symbiosis that I have been describing, in the progymnasmata and declamations of the rhetors, and in the display rhetoric cultivated by Greek philosophers for public performance, is a superficial phenomenon compared with the achievements of a Eudoxus or a Carneades when properly philosophising. But Cicero's solution is superficial. His own true achievement was to bring the flexibility and verve of oratory to the exposition of technical matters in his own philosophical works. But even here one has to remember that just as his material is very often Greek in origin, so too is his aspiration to express it rhetorically. In a remarkable passage of the Tusculans (1.7) he says: 'I have always thought the perfect philosophy to be the kind that could discuss the great questions in a full rich style. And to this practice I devoted myself with such enthusiasm that I even ventured to hold scholae in the Greek manner.' The model he was following in this practice was, he tells us, Aristotle.

NotA BENE. I have done little more than lightly annotate the paper I gave in Ouro Preto, which was intended to be provocative. Two friends were kind enough to comment on it: Tobias Reinhardt beforehand, Jaap Wisse afterwards. Dr. Wisse, who expressed strong reservations, hopes to return to the subject himself.

AвSTRACT. Cicero was anxious to bring about a rapprochement between oratory and philosophy, which had, he thought, been separated from each other since the time of Plato. He thought that an orator should be capable of speaking on abstract questions and of moving freely between the general and the particular, and that training in oratory should have some foundation in philosophy. This paper argues that the declamatory education that grew up after Plato took these aims into account, and that in the Second Sophistic as in the First it was possible for one and the same man to be both orator and philosopher.

Keywords. Education, Declamation, Philosophy, Cicero, Philostratus, First Sophistic, Second Sophistic. 